COMPETITOR: Jurnal Pendidikan Kepelatihan Olahraga

Volume 13 Number 2 Year 2021

e-ISSN: 2657-0734 \& p-ISSN: 2085-5389

This work is licensed under a Creative Commons Attribution 4.0 International License

\title{
Effectiveness of Bio-Energy Power to Improving VO2Max Futsal Players
}

\author{
Hendra Mashuri ${ }^{1^{*}}$, I Wayan Artanayasa ${ }^{2}$ \\ ${ }^{1,2}$ Faculty of Sports and Health/Sports Education/Ganesha University of \\ Education/Bali/Singaraja/Indonesia \\ 1,2 Jinang Dalem Singaraja Bali Village \\ 1hendra.mashuri@undiksha.ac.id, ${ }^{2}$ wayan.artanayasa@undiksha.ac.id
}

Received: April 21, 2021; Reviewed: May 7, 2021; Accepted: May 20, 2021;

Published: June 19, 2021

\begin{abstract}
Bioenergy power $(B E P)$ is a practice method that combines breathing and exercise to improve the quality of body cells for optimal body performance. Futsal is an aerobic game that requires oxygen in the formation of energy. Increased VO2Max will help the performance of futsal players. The purpose of this study to test the effectiveness of the BEP to the increase in VO2max futsal players beginners. This research is experimental quantitative research. The study population was beginner futsal players aged 10-12. The research sample used 30 futsal players. Signification test using paired t-test. The results of the research significance test showed that the t-count value was 14.807> t-table $1.699(d f=29)$. It can be concluded that the BEP effectively improve endurance capacity (VO2max) for futsal players beginners.
\end{abstract}

Keywords: bio-energy power; VO2Max; futsal

\section{INTRODUCTION}

Sports are all systematic activities to encourage, nurture and develop physical, spiritual and social potential (Law of the Republic of Indonesia Number 03, 2005). This mandate means that sport is an effort to encourage someone to develop physical potential which is manifested in increased abilities (Dlis, 2015), spiritual development manifested in the character of sports actors (Maksum, 2005), and social development manifested in the social behaviour of sports actors. (Cendra \& Gazali, 2019). This positions sports as an effective way to build a national culture with a wise character in social life.

Sport is simply a concrete impact on sportspeople biomotorik changes manifested in the ability of sport. Biomotor components or biomotor elements are the physical abilities of the human body (Nala, 2015). The biomotor components in sports are strength, flexibility, endurance, speed, and coordination (Bompa \& Buzzichelli, 2019). These biomotor components must be trained and maintained to get maximum results in 
Effectiveness Of Bio-Energy Power to Improving Vo2max Futsal Players

Hendra Mashuri $^{1 *}$ I Wayan Artanayasa ${ }^{2}$

hendra.mashuri@undiksha.ac.id

physical activity (Santika, 2017). The needs of the biomotor components for each sport are different, depending on the rules of the game and the form of the sport. However, endurance is a basic component needed by all sportsmen, given that sportsmen must do physical activity for a relatively long time (Mashuri, 2017). Therefore, training to improve and develop physical conditions (endurance) is needed (Mashuri et al., 2019).

Endurance is a state of the body that can complete sports activities without experiencing excessive fatigue (Bompa \& Buzzichelli, 2019; Mashuri, 2017). Endurance is often associated with physical fitness which can be seen from cardiorespiratory endurance. Cardiorespiratory endurance is a description of the ability of the cardiovascular and respiratory systems to meet the oxygen needs of muscles used during physical activity without experiencing excessive fatigue after completing these activities (Anggraeni \& Wirjatmadi, 2019; Dewi \& Muliarta, 2016). The cardiovascular system functions to supply oxygen to tissues that are used for muscle contraction during physical activity (Penggalih, Sofro, Solichah, Niamilah, \& Nadia, 2019). Blood that carries oxygen will be pumped by the heart in greater amounts so that the amount of oxygen circulated is also greater during physical activity. The respiratory system tries to provide oxygen to body cells and excrete carbon dioxide (Penggalih et al., 2019). The respiratory system is characterized by the exchange of air to and from the lungs, diffusion of oxygen and carbon dioxide, and the transport of oxygen and carbon dioxide to and from the lungs. The cardiovascular and respiratory systems are closely related to the supply and distribution of oxygen used in physical activities.

Cardiovascular and respiration systems will affect the performance of the body's endurance in physical activity. A common measurement of body performance (endurance) is to determine the maximum oxygen volume (VO2Max). VO2Max is the maximum amount of oxygen circulated and used per minute when the body performs maximum physical activity (Anggraeni \& Wirjatmadi, 2019; Penggalih et al., 2019). The VO2Max value is influenced by the cardiovascular system, the respiratory system, and skeletal muscle. In the cardiovascular system, it is related to the distribution of oxygen bound to haemoglobin which is used in skeletal muscles so that muscle contraction occurs during physical activity. The respiration system reflects the system of air uptake and exchange of oxygen and carbon dioxide.

VO2Max is also often referred to as aerobic capacity which means the maximum physiological activity that can be carried out by a person as measured by their oxygen consumption (Dewi \& Muliarta, 2016). VO2Max determines how intense a person can 
Effectiveness Of Bio-Energy Power to Improving Vo2max Futsal Players

Hendra Mashuri $^{1 *}$, I Wayan Artanayasa ${ }^{2}$

hendra.mashuri@undiksha.ac.id

do physical activity and is considered the best measure of the capacity of the cardiorespiratory system (Rodriguez, 2014). Thus VO2Max can provide endurance performance values in physical activity because endurance performance depends on the body's ability to take in and utilize oxygen to produce energy (Beck, Kipp, Byrnes, \& Kram, 2018). Therefore, endurance performance needs to be improved by training methods related to cardiorespiratory.

Bio Energi Power (BEP) offers a method of breathing exercises. BEP is a form of combined exercise and breathing exercises designed based on a medical theory to generate self-healing and optimize the body's metabolism. The human body can heal itself when sickness occurs, doctors only provide stimulation for the healing process (Sinya, 2007). Through movement and breathing, it will create physiological effects or body adaptations that stimulate several enzymatic chemical reactions in the body to emphasize homeostasis and oxidation of various food sources to maintain a sustainable energy supply (Abdurrahmat, 2006).

Physical activity by combining breathing and movement can cause hypoxia in the lungs, blood and body tissue cells, especially active muscle cells, and excess carbon dioxide (hypercarbia) (Nugroho, n.d .; Tapo \& Bile, 2020). This process will make the body's cells suffer from a lack of oxygen, lack of oxygen in the cells will result in cells getting better when conditions are normal or oxygen is sufficient. Hypoxic and hypercarbia conditions that occur can stimulate various work systems in the body ranging from the nervous system, cardiorespiratory system to the body's general work system to work more optimally.

Breathing exercises make the respiratory system function optimally by controlling the intake of oxygen. This control will cause air exchange to become obstructed and as a result, oxygen levels in the lungs and blood are lower. This has an impact on the supply of oxygen to body cells, muscles and body function experiencing a hypoxic exercise response (Giriwijoyo \& Sidik, 2013). This process can increase lung volume, clear secretions, improve gas exchange, control shortness of breath, increase exercise capacity and reduce pressure in the form of a relaxation response (Solomen \& Aaron, 2015).

BioEnergy Power (BEP) is a combination method of breathing and exercise to benefit from the breath training process combined with exercise. This combination is believed to be able to increase the endurance ability (VO2Max) of sports players. The BEP method consists of three moves, each of which has different movements with different breathing techniques. The three moves will be adjusted to the intensity of each 
person. So the length of holding your breath varies between people. However, usually, $\mathrm{BEP}$ is done in groups with one person as the leader who demonstrates and regulates the intensity of the breath and the number of movements.

Introduction typed in large letters [font Calisto MT 13 bold]. The introduction contains the background to overcome a problem, the urgency and rationalization of activities, literature review, problem-solving plans, activity objectives, and hypothesis [Font Calisto MT 12, justified, 1.5 spaces]. Articles are typed in Microsoft Office Word format. By using on A4 paper. Paper format 3-3-2-2 (left-top-right-bottom).

\section{METHOD}

This study uses a quantitative approach with a quasi-experimental comparative research type. The research design used was a randomized pre-test post-test design. The population of this study were beginner futsal players aged 10-12 years. Samples were taken randomly consisting of 30 futsal players. The treatment given to the sample was BEP training three times a week with an intensity of $60 \%-80 \%$. The research instrument was the VO2Max test by running $1600 \mathrm{~m}$ which was formulated with the Daniel Racing Formula (Daniels, 2005). The data analysis technique used is the t-test.

\section{RESULTS AND DISCUSSION}

Based on the results of a fitness test by running $1600 \mathrm{~m}$ and the Daniel Racing Formula, data on VO2Max from futsal players is obtained which is described as follows.

Table 1.

Description of VO2Max data

\begin{tabular}{lccc} 
& Pre-Test & Post-Test & D \\
\hline Average & 17,664 & 22,726 & 5,062 \\
Max & 20,58 & 26,89 & 8,16 \\
Min & 15,42 & 19,13 & 1,46 \\
Varians & 2,31 & 7,59 & 4,02 \\
SD & 1,52 & 2,76 & 2,01 \\
\hline
\end{tabular}




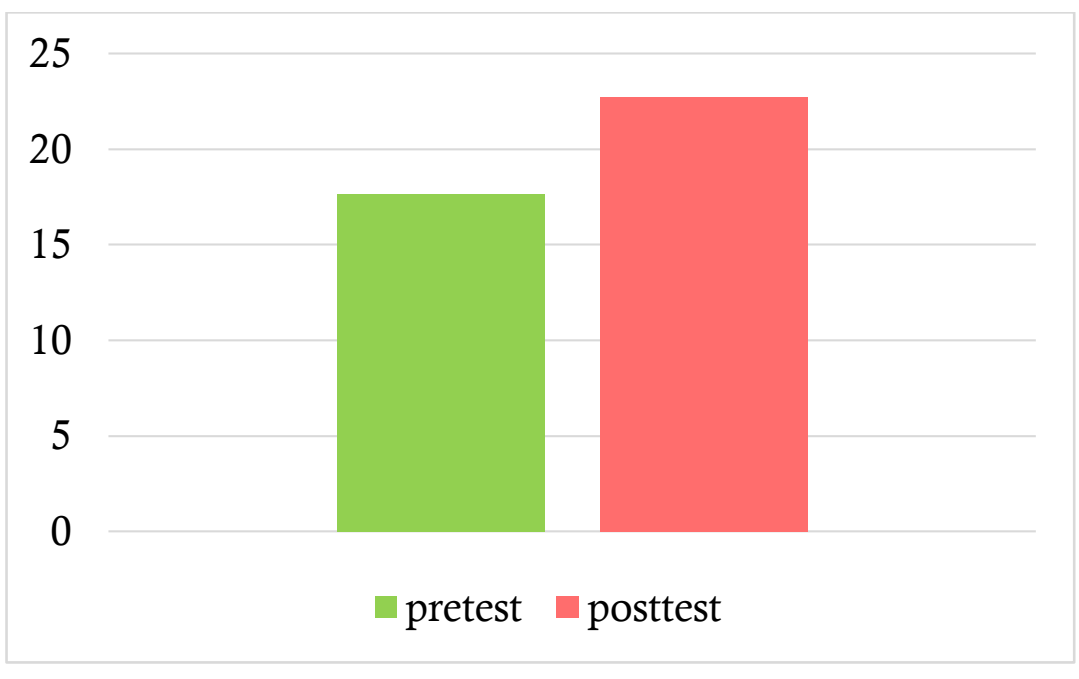

\section{Image 1. \\ Mean of VO2Max}

Based on the description of VO2Max data, it can be seen that the pre-test results show that the VO2Max average of beginner futsal players is $17.664(\mathrm{SD}=1.52)$ with the highest value of 20.58 and the lowest of 15.42. Meanwhile, after being given BEP treatment, the post-test results showed that the VO2Max average of beginner futsal players was $22.726(\mathrm{SD}=2.76)$ with the highest score of 26.89 and the lowest was 19.13. The difference between the pre-test and post-test scores is calculated for each futsal player.

After knowing the mean and SD values, test the statistical significance with the ttest. Paired t-test was used to test for changes in the dependent variable (VO2Max) in the group. The results of the paired t-test analysis are as follows.

Table 2.

The results of the t-test significance

\begin{tabular}{ccccc} 
& Mean & Std. Deviation & T & Information \\
\hline VO2Max & 5.06667 & 1.87420 & 14.807 & Significance \\
\hline
\end{tabular}

The result of paired t-test shows the value of $t$ count 14.807> t table $1.699(\mathrm{df}=$ 29) so that the mean difference of VO2Max pre-test and post-test is significant. Thus, training using bioenergy power can increase VO2Max for beginner futsal players.

Bioenergy power (BEP) is an exercise that combines breathing and exercise to improve endurance performance (VO2Max). Breathing is commonly referred to as controlling breathing, which means controlling the amount of oxygen that enters to 
Effectiveness Of Bio-Energy Power to Improving Vo2max Futsal Players

Hendra Mashuri $^{1 *}$, I Wayan Artanayasa ${ }^{2}$

hendra.mashuri@undiksha.ac.id

increase energy intensity by reducing the oxygen supply, which means that you have to be stronger in controlling your breathing (Giriwijoyo \& Sidik, 2017). Exercise in BEP is adjusted to the direction of the breath because it is related to the breathing process that involves the diaphragm, lungs, and other parts of the breath.

$\mathrm{BEP}$ using a combination of methods if the breath and if motion is essentially a body for healing energy utilization (increased function of body cells) (Nugroho, 2009). Efforts to improve endurance performance (VO2max) can be done by improving the function of body cells through the control of breathing.

Based on the research results, the BEP can significantly increase endurance performance (VO2max) futsal players beginners. BEP training process to control breathing futsal players beginners. This control aims to inhibit air exchange in the lungs which results in the oxygen content in the lungs and blood being reduced / lower than the resting state. This condition raises the supply of oxygen in the body's cells to become low. Thus, it can create training conditions in all cells of the body that is comprehensive (Giriwijoyo \& Sidik, 2017). The training of these body cells will improve the quality of cell function as a whole.

$\mathrm{BEP}$ is an exercise method that seeks to improve the quality of the smallest components in the body, namely cells by using the principles of hypoxia and hypercarbia. The improvement in the quality of cells that support endurance performance (VO2Max) is directly proportional to the increase in control of respiratory strength. The stronger it is to control breathing, the better the quality of the cells that support the cardiorespiratory system.

Futsal is an aerobic sport that requires oxygen in the process of building energy. The game of futsal requires endurance performance (VO2Max) in its game (Glänzel et al., 2020). The increase in VO2Max with a combination method of breathing and exercise is proven by Sudrajat \& Nisa (2016) which shows that regular breathing and exercise will increase the maximum volume of oxygen (VO2Max), strengthen the respiratory muscles so that the working power of the heart muscle and other muscles become better. The impact in futsal games is an increase in VO2Max for futsal players and an increase in the ability of the heart to pump blood throughout the body so that it will improve the quality of active muscles in futsal games. 
Effectiveness Of Bio-Energy Power to Improving Vo2max Futsal Players

Hendra Mashuri ${ }^{1 *}$, I Wayan Artanayasa ${ }^{2}$

hendra.mashuri@undiksha.ac.id

\section{CONCLUSIONS AND SUGGESTIONS}

Based on data analysis and discussion, it can be concluded that Bio-Energy Power (BEP) is effective in increasing the endurance ability (VO2Max) of novice futsal players. $\mathrm{BEP}$ can be a training alternative for coaches to increase VO2Max for futsal players.

It is suggested that there will be research on bio-energy power for other aerobic sports and to improve the fitness of school students so that bio-energy power can be included in physical education learning.

\section{REFERENCES}

Abdurrahmat, A. S. (2006). Bioenergi dalam Olahraga. Jurnal Sainstek, 1(3).

Anggraeni, L., \& Wirjatmadi, R. B. (2019). Status Hemoglobin, Kebiasaan Merokok, dan Daya Tahan Kardiorespirasi (VO2Max) Pada Atlet Unit Kegiatan Mahasiswa Bola Basket. Media Gizi Indonesia, 14(1), 27-34.

Beck, O. N., Kipp, S., Byrnes, W. C., \& Kram, R. (2018). Use Aerobic Energy Expenditure Instead of Oxygen Uptake to Quantify Exercise Intensity and Predict Endurance Performance. Journal of Applied Physiology, 125(2), 672-674.

Bompa, T. O., \& Buzzichelli, C. A. (2019). Periodization Theory and Methodology of Training (Sixth Edit). Champaign IL: Human Kinetics Publisher Inc.

Cendra, R., \& Gazali, N. (2019). Intensitas Olahraga Terhadap Perilaku Sosial. Media Ilmu Keolahragaan Indonesia, 9(1), 13-17.

Daniels, J. (2005). Daniels Running Formula (2nd Edition). Leeds, UK: Human Kinetics Publisher Inc.

Dewi, A. A. F., \& Muliarta, I. M. (2016). Daya Tahan Kardiorespirasi Siswa Pemain Basket Sekolah Menengah Atas di Kota Denpasar Lebih Baik dari pada Siswa Bukan Pemain Basket. E-Jurnal Medika, 5(4), 1-7.

Dlis, F. (2015). Sosiologi Olahraga. Malang: Wineka Media.

Giriwijoyo, H. S., \& Sidik, D. Z. (2013). Ilmu Kesehatan Olahraga. Bandung: PT Remaja Rosdakarya.

Giriwijoyo, H. S., \& Sidik, D. Z. (2017). Ilmu Kesehatan Olahraga (Edisi Keti). Bandung: PT Remaja Rosdakarya.

Glänzel, M. H., Geremia, J. M., Couto, A. N., Nepomuceno, P., da Rocha, G. G., Pohl, H. H., \& Reckziegel, M. B. (2020). Comparison of aerobic performance indicators of soccer and futsal athletes. Revista Brasileira de Medicina Do Esporte, 26(6), 513516. https://doi.org/10.1590/1517-86922020260620190015 
Effectiveness Of Bio-Energy Power to Improving Vo2max Futsal Players

Hendra Mashuri $^{1 *}$ I Wayan Artanayasa ${ }^{2}$

hendra.mashuri@undiksha.ac.id

Maksum, A. (2005). Olahraga Membentuk Karakter: Fakta atau Mitos. Jurnal Ordik, $3(1), 1-10$.

Mashuri, H. (2017). Shot-Shootan Basketball (Pertama). Nganjuk: CV. Adjie Media Nusantara.

Mashuri, H., Zawawi, M. A., Kholis, M. N., Junaidi, S., Pratama, B. A., Harmono, S., \& Jatmiko. (2019). Pelatihan Kondisi Fisik Dominan Bolabasket. JPPNu: Jurnal Pengabdian Dan Pemberdayaan Nusantara, 1(2), 42-52.

Nala, I. (2015). Prinsip Pelatihan Fisik Olahraga. Denpasar: Udayana University Press.

Nugroho, S. (n.d.). Senam Pernapasan Menurut Sudut Pandang Ilmu Faal Olahraga. Universitas Negeri Yogyakarta.

Nugroho, S. (2009). Terapi Pernapasan Pada Penderita Asma. Medikora, V(1), 71-91.

Penggalih, M. H. S. T., Sofro, Z. M., Solichah, K. M., Niamilah, I., \& Nadia, A. (2019). Gizi Olahraga II. Respon Adaptasi Biokimia dan Fisiologi Atlet (M. H. S. T. Penggalih, ed.). Yogyakarta: Gadjah Mada University Press.

Rodriguez, L. (2014). Cardiorespiratory Endurance Lake Sumter State. Sumterville, F1.

Santika, I. G. P. N. A. (2017). Pengukuran Komponen Biomotorik Mahasiswa Putra Semester V Kelas A Fakultas Pendidikan Olahraga dan Kesehatan IKIP PGRI Bali Tahun 2017. Jurnal Pendidikan Kesehatan Rekreasi, 1, 85-92.

Sinya, H. (2007). The Miracle Of Enzyme "Self-Healing Program". Surakarta: Qanita.

Solomen, S., \& Aaron, P. (2015). Breathing Techniques - A Review. International Journal of Physical Education, Sport, and Health, 2(2), 237-241.

Sudrajat, N. U. H., \& Nisa, K. (2016). Efektifitas Senam Asma untuk Meningkatkan Fungsi Paru Penderita Asma. Majority Journal, 5(4), 112-116.

Tapo, Y. B. O., \& Bile, R. L. (2020). Evektivitas Penggunaan Model Latihan Olahraga Pernapasan Monacors untuk Pemeliharaan Kesehatan Fungsi Paru Bagi Mahasiswa dalam Menghadapi Pandemi COVID-19. Ejurnal Imedtech, 4(2), 5465.

Undang-Undang Republik Indonesia Nomor 03, R. (2005). Sistem Keolahragaan Nasional. 